\title{
PALMAR DERMATOGLYPHICS: MASS SCREENING TOOL FOR HYPERTENSION
}

\author{
Abhilasha Setia ${ }^{1}$, Balreet kaur ${ }^{* 2}$, Nidhi Puri ${ }^{3}$, Ajitpal Singh ${ }^{4}$. \\ ${ }^{1}$ Demonstrator, Department of Anatomy, J.C.D. Dental College, Sirsa, Haryana, India. \\ ${ }^{* 2}$ Assistant Professor, Department of Anatomy, MMIMSR, MMU Mullana, Ambala, Haryana, India. \\ ${ }^{3}$ Professor and Head, Department of Anatomy, MMIMSR, MMU Mullana, Ambala, Haryana, India. \\ ${ }^{4}$ Professor and Head, Department of Anatomy, Desh Bhagat Dental College and Hospital, Desh \\ Bhagat University, Mandi Gobindgarh Punjab, India.
}

\section{ABSTRACT}

Background: Dermatoglyphics has been used as vehicle to resolve broader biomedical problems. It is a noninvasive \& non painful method of diagnosis. Palamer prints can be used as a screening tool for the hypertension.

Objectives: To find out the association of palmar dermatoglyphics with the hypertension.

Materials and Methods: Right palm prints were taken with the help of black inkpad on glossy paper and were observed using magnifying glass. Systolic and diastolic blood pressures were measured. The atd angle of right was measured.

Observations: The right palmar prints and the atd angles were found correlated with hypertension.

Conclusions: Larger the number of whorls on right hand and that too on index and ring finger greater is the systolic pressure. Persons with higher the atd angle were found hypertensive.

KEYWORDS: Dermatoglyphics, Whorls, Blood Pressure, atd angle.

Address for Correspondence: Dr Balreet Kaur, Assistant Professor, Department of Anatomy, MMIMSR, MMU, Mullana, Ambala, Haryana, India. Ph: 9896781105

E-Mail: balreet_81@hotmail.com

\begin{tabular}{|c|c|c|}
\hline \multicolumn{3}{|c|}{ Access this Article online } \\
\hline \multirow{2}{*}{$\begin{array}{l}\text { Quick Response code } \\
\text { DOI: } 10.16965 / \text { ijar.2017.202 }\end{array}$} & \multicolumn{2}{|c|}{$\begin{array}{l}\text { Web site: International Journal of Anatomy and Research } \\
\text { ISSN 2321-4287 } \\
\text { www.ijmhr.org/ijar.htm }\end{array}$} \\
\hline & $\begin{array}{l}\text { Received: } 27 \text { Mar } 2017 \\
\text { Peer Review: } 28 \text { Mar } 2017 \\
\text { Revised: None }\end{array}$ & $\begin{array}{l}\text { Accepted: } 08 \text { May } 2017 \\
\text { Published (O): } 31 \text { May } 2017 \\
\text { Published (P): } 31 \text { May } 2017\end{array}$ \\
\hline
\end{tabular}

\section{INTRODUCTION}

Dermatoglyphics, word from Greek language which means Derma- Skin Glyphic- Carving. All the primates have ridged skin and it can also be found on the paws of some mammals and on the tails of some monkey species [1]. Palmar printing is universal, unique, and permanent and collectable [2]. Any type of disturbed growth in earlier stages of foetal life may result in the abnormal pattern of Dermatoglyphics patterns though these anomalies are very rare [3]. All the physical traits genetically controlled and passed on from one generation to next generation according to law of inheritance by Mendel and features of dermatoglyphics are not exception [4].

The palmar prints can be classified according to three basic patterns namely Arches, Loops and Whorls. Normal palm has ten areas where these patterns found [5]. These patterns are classified according to presence of triradii. A triradii is a landmark formed by confluence of three dermal ridge systems. This forms a three pointed star (with the angle of 120 between each branch) or a triangular type pattern. Arch is the 
simplest pattern having no triradius, loop is having one triradius whereas whorl has two triradii [6]. Unusual dermatoglyphic patterns haves been often related to many disorders $[7,8]$. Dermatoglyphics can also be used to determine correlation of congenital heart defects with Down's syndrome, and craniofacial defects $[9,10]$. Diagnosis of some genetic syndromes can now be done on the basis of dermatoglyphics with high degree of accuracy in their prognostic ability [11]. Dermatoglyphic changes also seen in patients of the Bronchial asthma, Rheumatoid Arthritis, Carcinoma of cervix and Diabetes mellitus $[6,12-15]$ whereas some quantitative palmar parameters are having strong predictive strength of Diabetes mellitus [16]. Many genetic disorders reported unusual dermatoglyphic patterns. Therefore used in Diagnosis of genetic syndromes with high degree of accuracy. In the present study Dermatoglyphic ridges are correlated with the hypertension.

\section{MATERIALS AND METHODS}

For the present study prior informed consent of 113 subjects were taken. Subjects were chosen on simple random basis amongst persons belonging to North West Indian region. Prior informed consent for the study was taken both in English and vernacular languages from the subjects. The subjects were from the different age groups. Only the right hand prints were taken from the subjects, in sitting upright position on chair in relaxed state in normal Anatomical position. The subjects were advised not to change his position while measurements were taken. The prints were taken with the help of black inkpad on glossy paper using a foam pad on a flat surface and the prints were observed using magnifying glass. (Fig 1)

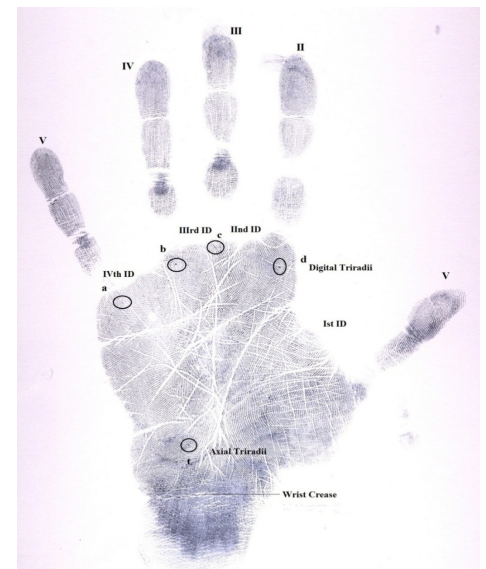

Fig. 1: Right hand print.
The systolic and diastolic blood pressure was measured with the help of sphygmomanometer. The subjects were classified into three groups normal, prehypertensive and hypertensive on the basis of blood pressure (according to Joint $\mathrm{Na}$ tional Committee on preservation, detection, evaluation and treatment of high blood pressure 7).

The atd angle was measured with the help of the goniometer (Fig 2). Subjects with congenital malformation of hand, apparent hand anomalies, inflammation, trauma, deformities and with the surgery of hands were excluded from the study.

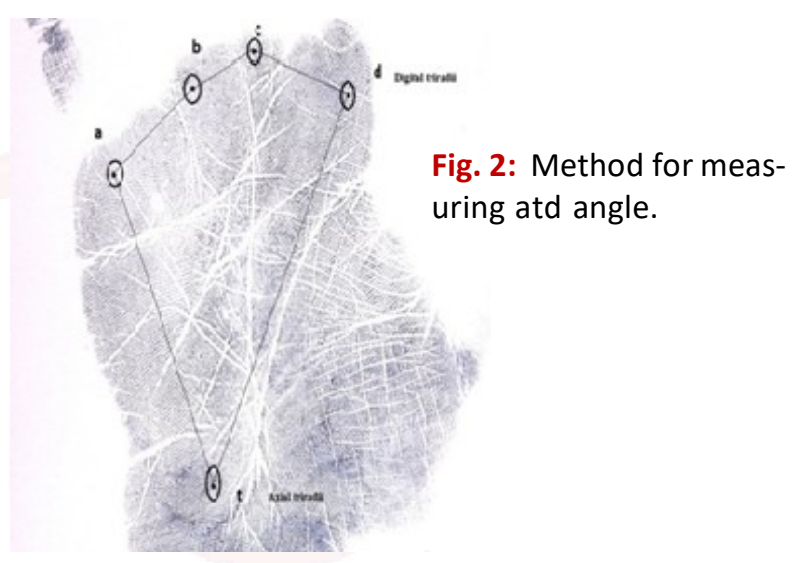

Criteria in hand print for the purpose of study: Palm prints examined by using magnifying glass, digital and axial triradii must be present, all triradii must be visible, no blank space present in the Centre of the palm, digital wrist creases should be located.

observations were made in digital prints: Patterns to be observed on digits were the arch, the loop and the whorl. The type of patterns depends upon the presence of number of triradii. Triardii is a point formed by the meeting of three different ridge fields. The arch is the simplest configuration, does not have a triradius. The loop, designated ulnar or radial depending upon the margin of hand to which it opens, has one triradius. The whorl forms a concentric design having two triradius.

Observations were made in palmer prints:

Each area in the palm is more or less distinct unit which is delineated by partial patterns in the form of loops or whorls. In the palms presence of the digital and axial triradii was observed (Fig: 1, 2). Triradii located at the bases of digits $(a, b, c, d)$ are digital triradii whereas $t, t^{\prime}, t^{\prime \prime}$ are 
axial triradii , present at the increasing distance from the base of the palm (Fig:1,2). atd angle was determined by drawing lines connecting triradii $\mathrm{a}, \mathrm{d}$ to $\mathrm{t}$ and was measured by using goniometer (Fig. 2).

The data was compiled, computed and analysed to calculate mean of quantitative variables with two standard deviations. Chi square test was used to calculate $p$ - values using software Epi Info.

\section{OBSERVATIONS}

Right palm prints obtained from the subjects were observed for digital prints patterns i.e. arches, ulnar loops, radial loops, whorls, double loops, mixed patterns and pocked loops. Each digit print was observed separately in the three groups i.e. Normal, prehypertensive and hypertensive. Among all digital print patterns ulnar loop were found predominantly on the digits of the subjects with normal blood pressure while the whorls were found predominantly on the digits of the subjects with high systolic blood pressure (Fig 3,4,5,6 and 7).

Fig. 3: First Digit Print Patterns in all the groups.

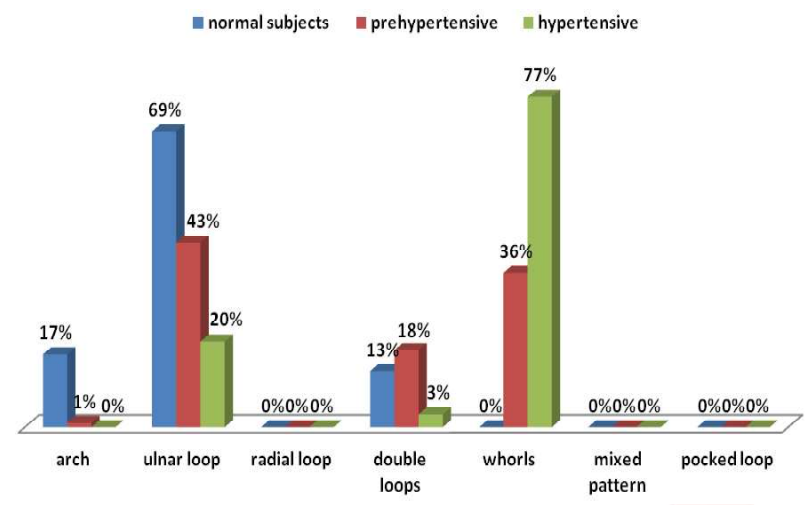

Fig. 4: $2^{\text {nd }}$ Digit Print Patterns in all the groups.

Inormal subjects prehypertensive hypertensive

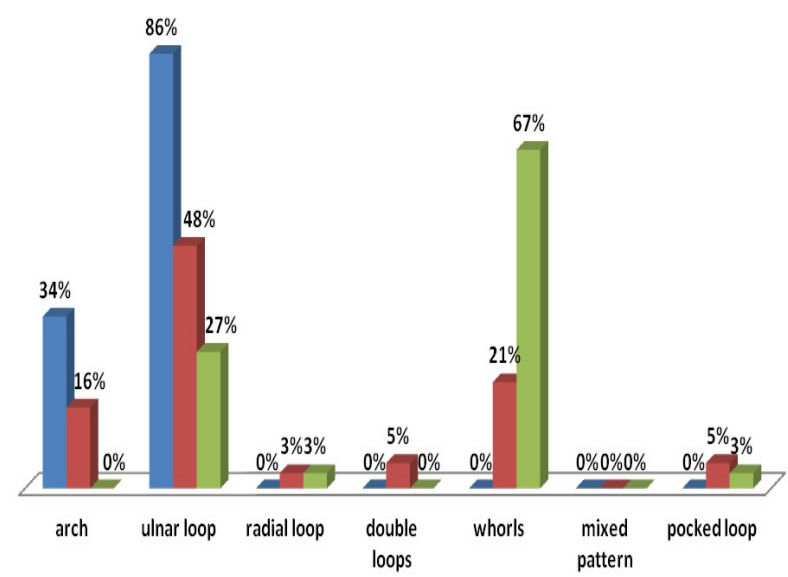

Fig. 5: $3^{\text {rd }}$ Digit Print Patterns in all the groups.

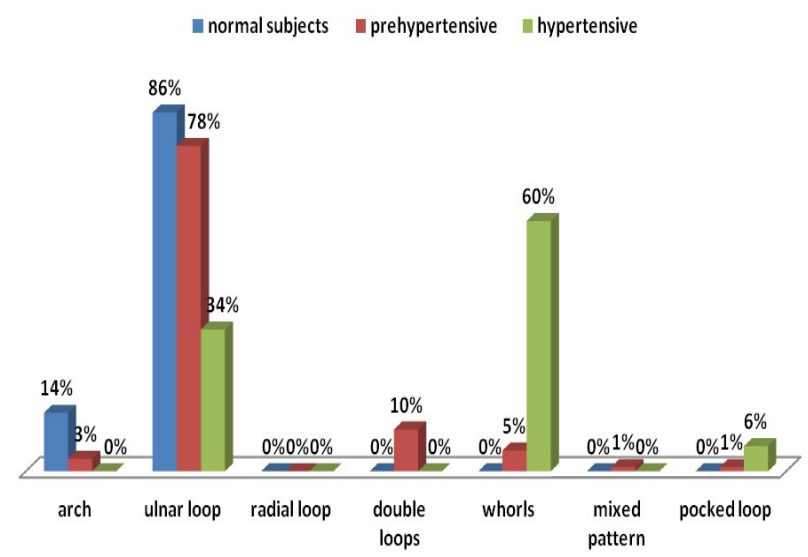

Fig. 6: $4^{\text {th }}$ digit print patterns in all the groups.

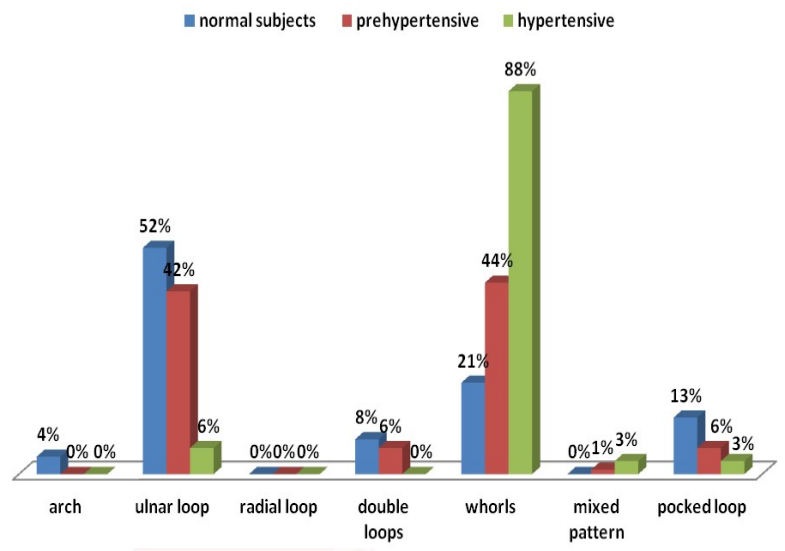

Fig 3 describes the print patterns found on the first digit i.e. $69 \%$ of the normal subjects were having ulnar loop patterns while $77 \%$ of hypertensive subjects were having whorl pattern on their first digit. Highest fluctuation is seen in the in case of second and fourth digit i.e. $86 \%$ and $52 \%$ of normal subjects were observed with ulnar loops while $67 \%$ and $88 \%$ of hypertensive subjects were with whorls on their second and fourth digit respectively (Fig 4\& 6). Radial loop patterns were present only in the second digit

Fig. 7: 5th digit print patterns in all groups.

Inormal subjects aprehypertensive inypertensive

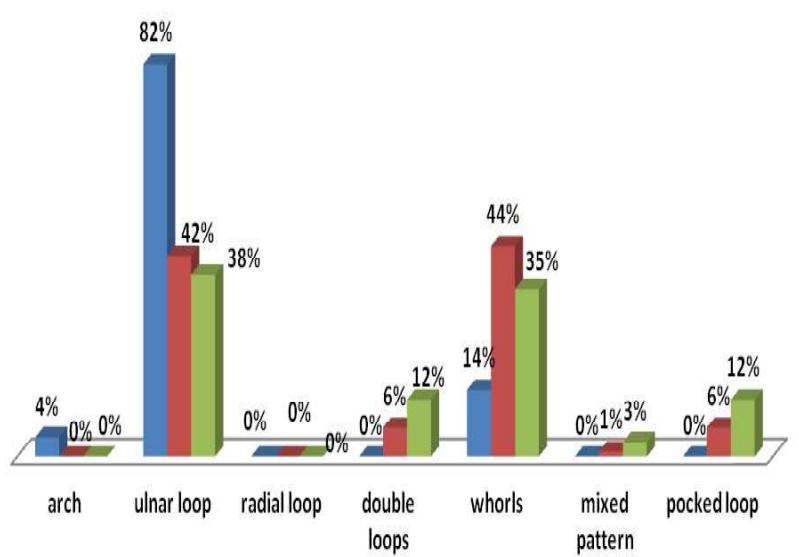


print patterns of hypertensive and prehypertensive group subjects. Maximum number of ulnar loops among normal subjects were present on the $2^{\text {nd }}$ and $3^{\text {rd }}$ digit i.e. $86 \%$ followed by $82 \%$ on $5^{\text {th }}$ digit (Fig 4, 5, 7). No arch print patterns reported among hypertensive group on all the digits.

Applying chi square test reveals index and ring fingers were found to have whorls in the maximum number of hypertensive subjects. atd angle was observed in the subjects of three groups it was found more than 40 in the subjects of hypertensive group than subjects of normal and prehypertensive groups (Fig 8).

Fig. 8: atd angle in all the three groups.

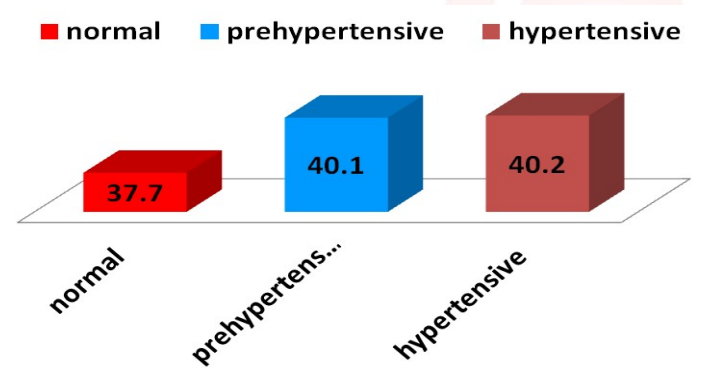

Among all digits index and ring fingers were found with maximum number of whorls and statistically highly significant (with $p$ values 0.0000005 and 0.000016 respectively) for the determination of hypertension.

\section{DISCUSSION AND CONCLUSION}

Dermatoglyphics has been studied extensively in chromosomal disorders, single gene disorders and those disorders whose genetic basis is not clear. Hypertension being a silent killer causes the heart attacks. The percentage of cases of hypertension has increased rapidly among both males and females. In the present study the palmar dermatoglyphics was used to see it's correlation with the hypertension. The whorls and atd angle were found to be correlated with the hypertension. The number of whorls was found more on the digits of the subjects of the hypertensive group. The results were found highly significant statistically too $(p<0.05)$. Rudragouda S B et al also found the similar results in their study done on males and females of the age group 20-50 years. They also concluded that there were some predisposing genetic factors causing the hypertension and dermatoglyphics that could help in predicting person's chance of acquiring hypertension [17]. Buddhika et al also reported consistent finding of an increased frequency of whorl patterns along with a higher mean total ridge count in digital dermatoglyphic in hypertensive subjects [18]. Arsita et al reported the higher frequency of double loop whorl patterns in hypertensives [19]. While in another study done by Umana et al a significant association between fingerprint pattern and hypertension was found. In this study lip print pattern and hypertension were also found correlated in the female subjects but males showed no association between fingerprint patterns and hypertension however the lip print patterns showed significant association with hypertension [20]. In the present study atd angle was also found increased in subjects of the hypertensive group. Few similar studies were also found in the support of correlation between atd and hypertension [19,21]. While Oladipo GS et al found no correlation between atd and hypertension [22].

From the present study it was concluded that the whorls and atd were highly correlated with the hypertension $(<0.05)$. atd angle $d$ " 40 has more the predictive value than whorls in increase in blood pressure Among all digits index and ring fingers were found with maximum number of whorls and statistically highly significant (with $p$ values 0.0000005 and 0.000016 respectively) for the determination of hypertension. Dermatoglyphics can be used as mass screening tool to identify potential cases of high blood pressure which can further be followed for preventive as well as curative measures.

\section{Conflicts of Interests: None}

\section{REFERENCES}

[1]. Miller JR. Dermatoglyphics. Journal of investigative Dermatology 1973;60(6):435-42.

[2]. Jasuja OP, Singh GD, Kumar M. A Dermatoglyphic Study in cases of polydactyly and syndactyly. Anil Aggerwal's Internet Journal of forensic medicine and toxicology 2010[JAN-JUNE]; 11(1): [21 SCREENS]. Available from: URL:httpp://geradts.com/anil/ij/ vol_011_no_001/papers/paper002.html

[3]. Bromba GmbH. Bioidentification frequently asked questions [Internet]. 2011 [updated 2011 Dec 19; cited 2011 Sep 12]. Available from: http:// www.bromba.com/faq/biofaqe.htm 
[4]. Kumbhani HK. Dermatoglyphics : A review. Delhi: Kamla-raj enterprises; 2007.p.285-95 (Anthropology today: trends, scope and applications; vol 3).

[5]. Gibbs RC. Fundamentals of Dermatoglyphics. Arch Derm 1967;96:721-25.

[6]. Gupta UK, Parkash S. Dermatoglyphics: A study of fingertip patterns in bronchial asthma and its genetic deposition. Kathmandu University Medical Journal. 2003;1(4):267-271.

[7]. Shiono H. Dermatoglyphics in medicine. Am J Forensic Med Pathol 1986;7(2):120-6.

[8]. Katznelson M, Goldman B. Fetal dermatoglyphics. Clin Genet. 1980;21(4):237-42.

[9]. Durham N, Koehler J. Dematoglyphic indicators of congenital heart defects in Down's syndrome patients: A preliminary study. J Ment Defic 1989;33(4):343-48.

[10]. Jahanbin A. Dermatoglyphic analysis in parents with nonfamilial Bilateral Cleft lip and palate children. The Cleft-Palate Craniofacial Journal 2010;47(1):914.

[11]. Natekar PE, Desouza FM. Fluctuating asymmetry in Dermatoglyphics of carcinoma of breast. Indian Journal of Human Genetics 2006;12(2):76-81.

[12]. Rajangam S, Ravindranath R, Shubha R, Nagesh HV, Johnson J. Dermatoglyphics- Quantitative analysis in Rheumatoid arthiritis. Anthropologist 2008;10(3):233-35.

[13]. Inamdar VV, Vaidya SA, Kulkarni P, Devarshi DB, Kulkarni S, Tungikar SL. Dermatoglyphics in carcinoma of cervix. J. Anat.soc. India 2006;55(1):57-59.

[14]. Dam PK, Joshi V, Purohit A, Singh H. Dermatoglyphic patterns in Diabetes mellitus patients and Non-Diabetics: A preliminary study. Jodhpur: DMRC;2007$08.4 p$.
[15]. Vani VV, Kamath SK, Naik LD. The palm print as a sensitive predicator of difficult laryngoscopy in diabetes: a comparison with other airway evaluation indices.2000;46(2):75-9.

[16]. Ravindranath R, Joseph AM, Bosco SI, Rajangam S, Balasubrmanyam V. Fluctuating asymmetry in dermatoglyphics of non-insulin-dependent Diabetes mellitus in Bangalore based population. Indian Journal of Human Genetics 2005;11(3):149-153.

[17]. Rudrgouda SB et al. Study of palmar dermatoglyphics in patients with essential hypertension between the age group of 20-50 years. Int J Med Res Health Sci. 2013;2(4):773-9.

[18]. Buddhika TBW, Robert JM, Thilini CA and Suneth BA. Dermatoglyphics in hypertension: a review. J Physiol Anthropol. 2015;34(1):29.

[19]. Lahiri A, Bandyopadhyay S, Adhya S, Ghosh S, Goswami S, Bhattacharya P. A study on relationship between dermatoglyphics and hypertension. J Dent Med Sci. 2013;7(6):62-5.

[20]. Umana et al. Dermatoglyphics and Cheiloscopy Pattern in Hypertensive Patients; A Study in Ahmadu Bello University Teaching Hospital, Zaria, Nigeria and Environs. Int J Sci Res Pub. 2014;4(5).

[21]. Brunson EK et al. Reliabiliy of the atd angle in dermatoglyphics [Internet]. [ Cited 2017 Feb12]. Available from https://djholman.csde.washington.edu/ working/2006-1.pdf.

[22]. Oladip GS, Osogba IG, Bobmanuel I, Ugboma HAA, Sapira MK, Ekene ON. Palmar dermatoglyphics in essential hypertension in essential hypertension amongs Rivers Indigenes. Aust J Bas App Sci. 2010;4(12):6300-5.

How to cite this article:

Abhilasha Setia, Balreet kaur, Nidhi Puri, Ajitpal Singh. PALMAR

DERMATOGLYPHICS: MASS SCREENING TOOL FOR HYPERTEN-

SION. Int J Anat Res 2017;5(2.2):3850-3854. DOI: 10.16965/ ijar.2017.202 